A N N A L E S

UNIVERSITATIS MARIAE CURIE-SKŁODOWSKA LUBLIN - POLONIA

VOL. XXX, 1

SECTIO J

2017

Uniwersytet SWPS w Warszawie. Wydział Zamiejscowy w Poznaniu

\title{
TERESA RZEPA
}

trz@data.pl

\section{O duchowości i jej rozwoju w dzienniku komputerowym Zbigniewa Pietrasińskiego}

On Spirituality and Its Development in Zbigniew Pietrasiński’s Computer Diary

\section{STRESZCZENIE}

W artykule zaprezentowano poglądy Zbigniewa Pietrasińskiego (zawarte w jego dzienniku komputerowym) na temat: 1) rozumienia pojęć: „duch”, „dusza” i „duchowość”, 2) religii katolickiej i jej wyznawców oraz Kościoła katolickiego, 3) istoty i przebiegu rozwoju duchowego w ujęciu modelowym.

Słowa kluczowe: poglądy Zbigniewa Pietrasińskiego; dusza; duchowość; rozwój duchowy

\section{WPROWADZENIE}

Zbigniew Pietrasiński (1926-2010) jest autorem kilkunastu wartościowych książek popularyzujących osiągnięcia psychologii i psychodydaktyki. Jako wytrawny uczony i wykładowca potrafił wyjątkowo zajmująco, a jednocześnie przystępnie, przybliżać naukową wiedzę z takich obszarów, jak psychologia myślenia, psychopedagogiczne metody i techniki uczenia się czy kształtowania przydatnych umiejętności oraz nawyków życiowych i zawodowych. Wypowiadał się też na temat innowacyjności i psychologii zarządzania. Wyróżnionym obszarem jego zainteresowań była psychologia mądrości i rozumnego korzystania z tak wyjątkowych dyspozycji osobistych, jak kompetencja autokreacyjna i biograficzna. Jeśli 
ktoś potrafi je odpowiednio i systematycznie wykorzystywać, to - zdaniem Pietrasińskiego (2009) - zyskuje szansę na osiągnięcie „pełni człowieczeństwa”, zarezerwowanej dla „renesansowych, pięknych umysłów”. Psychologicznie skomplikowana, choć dzięki mądrości możliwa, droga ku tak fascynującemu celowi zawiera się w prostym wyrażeniu, traktowanym zarazem jako życiowy drogowskaz i ogólna reguła życiowa: „Być kowalem własnego losu”.

Właściwie większość zagadnień zanalizowanych i spopularyzowanych przez Pietrasińskiego można sprowadzić do szeroko rozumianej sztuki życia, odnoszonej przeważnie do mądrości i stale poszerzanego zasobu wiedzy autobiograficznej, zbudowanej na nieustannie pogłębianej autorefleksji. Bowiem tylko samoformujący się człowiek potrafi dokonywać krytycznego oglądu i konstruktywnej oceny własnych potrzeb, pragnień i motywów, decyzji i postępków; umie przyznać się do błędów i potrafi znajdować efektywne rozwiązania problemów życiowych; unika stosowania strategii ucieczkowych i życzeniowego myślenia, a przy tym konsekwentnie i skutecznie modyfikuje wadliwe schematy własnego postępowania i ulepsza te, które doprowadziły go do wyznaczonego celu. Tak istotnych zmian może dokonywać wyłącznie ten człowiek, który nie tylko wie, że żyje „tu i teraz", a więc może na bieżąco regulować bieg własnego życia, lecz również pamięta o tym, iż jest „produktem i emanacją przeszłości”, dzięki czemu może swe życie regulować biograficznie. Ponadto wie, że obie te formy regulacji pozwalają na wyznaczanie nowych celów i skuteczne rzutowanie się w przyszłość, a tym samym pełne korzystanie z własnych doświadczeń życiowych.

Pietrasiński poświęcił sztuce życia pięć książek autorskich (1977, 1979, 1990, 2001, 2009), dwie pod swoją redakcją $(1997,2000)$ i kilkanaście artykułów naukowych (m.in. 1987, 1988, 1992, 1993, 2003). Jednocześnie, w prowadzonym przez 40 lat osobistym dzienniku ${ }^{1}$, w tym spisywanym przez blisko 20 lat $\mathrm{w}$ formie komputerowej (Pietrasiński, 2015), systematycznie odnotowywał wszelkie obserwacje, pomysły, refleksje, sytuacje i wydarzenia życiowe, które dotyczyły tego zagadnienia. Kreślił w nim również modele dróg życiowych i projektował metody pozwalające na doskonalenie się w wyjątkowej, choć przecież dostępnej

${ }^{1}$ Bogatą, liczącą kilka tysięcy stron, spuściznę po Zbigniewie Pietrasińskim, na którą składają się teksty o charakterze naukowym i autobiograficznym, otrzymałam od p. Marii Pietrasińskiej, zgodnie $\mathrm{z}$ wolą wyrażoną w zapisie testamentowym jej Męża. W tym miejscu wyjaśniam, że przez pierwszych 20 lat (od 1970 do 1990 r.) Zbigniew Pietrasiński zapisywał najczęściej odręcznie (rzadziej na maszynie) swe refleksje, opinie, anegdoty, recenzje, projekty artykułów, książek czy zadań dydaktycznych, a także relacje z różnych wydarzeń. Część dziennikowych zapisków, datowanych na lata 1991-2010 i poczynionych w formie komputerowej (10\% całości komputerowego dziennika), została opublikowana w 2015 r. (Pietrasiński 2015). Stąd też przywoływane w niniejszym tekście cytaty opatrzone wyłącznie datą pochodzą albo z owej nieopublikowanej części (90\% całości) komputerowego dziennika, albo z wcześniejszych zapisków Pietrasińskiego zawartych w (przeważnie odręcznie) prowadzonym dzienniku osobistym. Wszystkie te materiały są przechowywane w moim prywatnym archiwum. 
każdemu człowiekowi, sztuce życia. Dlatego też bardzo bogaty treściowo dziennik Zbigniewa Pietrasińskiego stanowi nader cenne źródło ,gorącej” wiedzy psychologicznej. Jako że mieszczą się w nim także poglądy na temat duchowości i jej rozwoju, odpowiednie fragmenty tego dokumentu są głównym przedmiotem refleksji zawartych w niniejszym opracowaniu.

\section{DUCH, DUSZA I DUCHOWOŚĆ}

Najpierw warto przyjrzeć się temu, jak Pietrasiński rozumiał i w jakich kontekstach używał kluczowych pojęć. Otóż okazuje się, że wbrew Anaksagorasowi i Platonowi oraz innym wielkim filozofom, którzy pojmowali ducha jako pierwszą zasadę ruchu, czystą aktualność, ideę dobra, ,poruszyciela”, rozumną siłę napędową materialnego porządku i ruchu w świecie, Pietrasiński rozumiał ducha i/lub duszę jako humanistyczną metaforę służącą określaniu uogólnionego klimatu psychicznego, doświadczanego nastroju, aktualnie przeżywanego stanu emocjonalnego bądź traktował je jako oznaczające rdzeń, istotę, samo sedno czegoś/ kogoś lub danej dyspozycji psychicznej.

Przykładowo 10 lutego 1973 r. pod wpisem zatytułowanym Radosny zwrot Pietrasiński zanotował:

Dziś patrzę na potworną, czarną, zdeformowaną twarz, którą w ub. poniedziałek Wanda [córka - T.R.] namalowała na czerwonym kartonie. Przyjąłem ją wtedy za aktualny portret mej duszy. Ogarnia mnie przerażenie, że mogłem być w takim stanie. Ale teraz już do tego nie wrócę. Zły los wyczerpał swe uderzenia. Znów idę wzwyż... Będę usilnie jak nigdy pracował nad swym charakterem i wydajnością. Ponawiam marzenie, by stać się mistrzem gratyfikacji, rozwijania ludzi...

A w sobotę, 12 marca 1994 r., po raz któryś z rzędu powrócił do problemu osobistej tożsamości i z odkrywczą radością zapisał:

Ad moja tożsamość: pragnąc udoskonalić swą książkę, szukam przykładów refleksji wielkich umysłów do podrozdziału o refleksji i sięgam do [Michela] Montaigne'a, Seneki, [Witolda] Gombrowicza, [Jacquesa] De Bourbon Busseta. W tym ostatnim odnajduję bratnią duszę: innymi środkami obaj realizujemy podobną misję. Pisze on: „Jak pomóc każdemu w uformowaniu i zrealizowaniu swego zamierzenia życiowego? Nie potrafię się wyrzec tej szalonej ambicji”. A w innym miejscu: „Moim podstawowym wyborem było zawsze: pomagać żyć temu, kto na mnie liczy” (Pietrasiński 2015, s. 52).

Na tym według Pietrasińskiego polegało braterstwo ich dusz. Ale też potrafił używać tego pojęcia w kontekście nie tak wzniosłym. Na przykład 1 lipca 1972 r. zanotował: „Cała ta dydaktyczna praca będzie trudem syzyfowym, jeśli nie stanie się jedynie pożywką dla prężnej, frapującej popularyzacji. Steruję tedy na intensywne pisanie i wciąganie w jego nurt innych (co na to mój dobry duch, burzący ciasne opłotki prakseologii?)”. W podobnym „duchu” została utrzymana notatka 
z 26 września 1994 r.: „Wstałem w dobrym, energicznym nastroju. (...) Pochwała tego dziennika: 24.9. przeglądałem pliki z materiałami do wykładów i znalazłem przeniesiony z dziennika fragment o tym, że (...) moje pierwsze wykłady w r. ub. były oceniane jako bardzo dobre. To podniosło mnie na duchu".

Kiedy do domu państwa Pietrasińskich przybywali zaproszeni goście, to o ich samopoczucie fizyczne troszczyła się żona, p. Maria, która przygotowywała wyśmienite uczty kulinarne. Zaś małżonek przygotowywał „dania” służące poprawie psychicznego samopoczucia gości, zaskakując ich tzw. przekąskami dla ducha. Zazwyczaj układał je pod przykrywą wielkiego, srebrnego półmiska, jak np. w poniedziałkowy wieczór 19 kwietnia 1999 r.:

Menu do „zakąski dla ducha” na dzisiejsze party. Kupiłem następujące książki: Lem S. (1999). Bomba megabitowa. Kraków, Wydawnictwo Literackie. 25 zł; Libera A. (1998). Madame. Kraków, Wydawnictwo Znak. (Główna nagroda Znaku za powieść w 1997 r.). 26 zł; Canfield J., Hansen M.V., Rogerson M., Clauss T. (1998). Balsam dla duszy pracujacej. Poznań, Wyd. REBIS. 19 zł; Kapuściński R. (1998). Heban. Warszawa, Czytelnik. 33 zł; Lourie R. (1999). Autobiografia Stalina. Kraków, Wyd. Znak. 27 zł (...).

Lista książek do wyboru i „nakarmienia” ducha każdego spośród gości była zawsze długa, a książki równie ,świeże” i „smakowite”, jak serwowane potrawy dla ciała.

Genezy wyjątkowego pomysłu na radosne uraczanie gości „,czymś dla ducha i czymś dla ciała" można się doszukać w wypowiedzi z 3 września 1992 r., kiedy to Pietrasiński rozważał problem kryteriów, jakimi warto się kierować przy podejmowaniu życiowo ważnych decyzji:

Co wybierać? Istota mądrości - w ocenie wartości rzeczy i opcji... (...) Jak wybierać spośród wielu dobrych rad? Jak wyławiać z morza wiedzy najcenniejsze ryby? Idea: Kiedyś problemem była tajemniczość i trudny dostęp do ważnych rad i ważnej wiedzy. Dziś problemem jest trafny wybór z nadmiaru obfitości... Jałowe pożywienie dobrze robi naszemu ciału. Jałowe wiadomości zasuszają naszą duszę.

Aby zatem od-jałowiać, a co najmniej nie zasuszać, dusz swoich gości, Pietrasiński proponował wzbogacanie ich wartościowym „pokarmem” w postaci książek starannie wybranych ,z nadmiaru obfitości” księgarskich półek.

8 marca 1995 r. Pietrasiński poświęcił sporo miejsca rozważaniom nad teoretycznym modelem mądrości i tak go pokrótce scharakteryzował: „(...) istnieją 2 układy. Pierwszy to dana osoba, drugi - to idealny mędrzec lub zdepersonalizowany program (programator). Lepszy będzie program bezosobowy. Może nazwać go radą mędrców? Albo duchem mądrości?”. W tym przypadku „duch mądrości” oznacza sens i głębię układu, gdyż odpowiada jego „oprogramowaniu”, które należy rozumieć jako złożoną dyspozycję psychiczną. Ale przecież można pod poję- 
cie duchowego „oprogramowania” podstawić różne treści, jak wymienione przez Pietrasińskiego 30 kwietnia 2005 r. ,,modlitwa, medytacja, studiowanie poważnych dzieł, walka z pokusami, panowanie nad sobą, samosterowność".

Można również użyć pojęcia „,duch” na określenie typu człowieka, nawet: niepełnowartościowego, nieposiadającego dostatecznych zasobów poznawczych, tak jak uczynił to Pietrasiński 5 kwietnia 1995 r., kiedy sformułował dwie interesujące zagadki: „Zagadka: Kiedy oszczędzanie zubaża? Gdy jest oszczędnością w myśleniu i formuje człowieka ubogiego duchem. Zagadka: Czym procentuje oszczędzanie na myśleniu? Przyrostem liczby ubogich duchem”. „Ubodzy duchem" występują w dzienniku wielokrotnie i zawsze w znaczeniu ludzi „wybrakowanych", niepełnych pod jakimś względem. Na przykład 9 marca 1996 r. Pietrasiński odsądził osoby tego rodzaju od umiejętności zdrowego krytycyzmu, gdy zanotował:

Wróciła mi radość pisania. Zacząłem na nowo komponować książkę „Drogi do mądrości”. Czuję, jak gwałtownie wyrastam z psychologii, odrzucam skorupy zawodowych ograniczeń. Nie oglądam się na konwencje językowe i horyzonty ludzi, którzy nie używając epitetu „głupota”, rozsiewają głupotę w swych nadgeneralizacjach dla anemicznych duszyczek niedojrzałych.

„Nadgeneralizacjami” nazywał Pietrasiński podawane do wierzenia ludziom „płytkim”, „ubogim duchem”, „niedojrzałym”, ,anemicznym duszyczkom” o ,zaszpuntowanych/zagwożdżonych umysłach" rozmaite psychologiczne quasi-mądrości, często wynikające wyłącznie z własnego doświadczenia lub widzimisię psychologa przekonanego o posiadaniu prawa do tworzenia reguł ogólnych, wysnutych po przesączeniu pojedynczego faktu przez fałszujący rzeczywistość bo również pojedynczy - filtr swego umysłu.

Pietrasiński wiedział aż nadto, ile wysiłku kosztuje uważne prześledzenie biografii i autobiografii, pamiętników, dzienników i wspomnień po to, aby odkryć i sformułować choćby jedną zasadę rządzącą biegiem ludzkiego życia. W pełni zgadzał się z opinią Charlotty Bühler (1933/1999), która jako pierwsza zasygnalizowała ogrom trudności empirycznych i teoretycznych, jakie napotyka każdy, kto bada prawidłowości dotyczące przebiegu ludzkiego życia oraz sztuki jego przeżywania. Dlatego spłycanie tego problemu i podawanie niewiarygodnych (bo niezweryfikowanych) reguł sterowania własnym życiem tak bardzo poruszało Pietrasińskiego. Oceniał bowiem, że bezkrytyczne przyjmowanie i stosowanie się do tych reguł przez naiwne i ,niedojrzałe duszyczki” czyniło z takich ludzi wyjątkowo nieskutecznych „kowali własnego losu”. Wszak naiwne i bezrefleksyjne, a tym samym nieefektywne ,wykuwanie” własnego losu prowadzi do ,prawdzi-

${ }^{2}$ Tę „zagadkę” w zmienionej formie powtórzył Pietrasiński (2015, s. 161) 30 grudnia 1997 r., odpowiadając na postawione pytanie bardziej dosadnie, iż „oszczędzanie na myśleniu procentuje $»$ kretynieniem«". 
wego kalectwa”, równoznacznego z „kalectwem duchowym”. 10 września 1995 r. mocnymi słowy Pietrasiński zdefiniował ludzi dotkniętych tą ułomnością:

Kaleką jest człowiek, który nie cierpi wysiłku. (Lepiej: Kaleką jest człowiek, który nie znosi wysiłku i nie lubi zdrowego zmęczenia.) Ułomny jest z wizją życia jako sielanki bez konfliktów. Kaleką jest uczeń, który nie cierpi uczenia się. Który nie umie rozkazywać samemu sobie. Kaleką jest rozkoszniaczek, który umie sobie tylko dogadzać, a nie rozkazywać. Kalectwo duchowe szerzą grupy uczniaków narzucających kolegom standardy intelektualne kretyna.

Pietrasiński stale powracał do zagadnienia sztuki życia jak do - jego zdaniem - najważniejszego problemu psychologicznego, który usiłował zawrzeć w dręczących go i jakże istotnych pytaniach. Poszukiwał na nie odpowiedzi wszędzie, gdzie to było możliwe, a najczęściej w dokumentach biograficznych pochodzących tak od sławnych, jak i zwykłych ludzi. Jak mądrze kierować swym życiem? Jak rozpoznawać i wykorzystywać swój potencjał? Jak stawać się mądrym i pełnym, autokreującym się człowiekiem? Jak uczyć się na swej biografii, czyli jak prawidłowo używać kompetencji biograficznej? Jak korzystać z wiedzy o sukcesach innych ludzi oraz o sposobach ich osiągania? Jak unikać błędów życiowych i bolesnych porażek? Czy warto w tym zakresie odwoływać się do metod stosowanych przez inne osoby? Jakimi kierować się kryteriami, aby trafnie oceniać swoje postępowanie? Jak sprawić, aby w bagażu indywidualnej wiedzy zatrzymać te wzorce zachowania, które okazały się wyjątkowo skuteczne? Jak pozbywać się negatywnych nawyków i fałszywych przekonań wdrukowanych nam przez otoczenie społeczne?

Takie i tym podobne pytania przewijają się przez tysiące kart dziennika i wyraźnie pokazują, jak bardzo jego autor interesował się i niepokoił trudnościami i zawiłościami związanymi ze sztuką życia, jak się w tę sztukę angażował i jak bardzo był nią przejęty. Oczywiście był także gotów do ciągłej refleksji nad własnym życiem oraz do oceny swego postępowania, a także co pewien czas projektował i modyfikował różne zadania i gry psychologiczne, których celem było nie tylko dotarcie do przemyśleń i obserwacji innych ludzi, lecz również nakłonienie ich do systematycznego pochylania się nad biegiem swego życia i korzystania z nabywanej tym sposobem życiowej mądrości. Dziennik jest gęsto przetkany projektami tego typu gier, poleceń, tematów wypracowań, ćwiczeń i testów. Zawiera też ich najciekawsze rozwiązania w postaci pojedynczych zdań syntetyzujących dotychczasowy bieg życia, opisów największych sukcesów i porażek oraz sposobów radzenia sobie z nimi czy też najważniejszych spostrzeżeń i obserwacji życiowych ujętych w formie porad i zaleceń (,przykazań”) skierowanych do innych ludzi. Dziennik zawiera również argumenty i racjonalizacje tych osób, które oceniły zajmowanie się sztuką życia jako beznadziejne kręcenie się wokół problemu nie do rozwiązania, a więc jako działalność całkowicie zbędną i nużącą. 
Oto przykładowe zadanie, opracowane 11 grudnia 1994 r. z intencją zrealizowania go podczas zajęć z menedżerami³:

Napisz tekst o objętości 1-2 stron pt. „Selektywna historia mego rozwoju, widziana przez pryzmat odziedziczonych i własnych dyrektyw postępowania, w tym - przykazań mądrości”. Przez dyrektywy (przykazania) własne należy rozumieć te, które sam dodałeś do przykazań wpojonych Ci przez otoczenie. Mogą to być przykazania sformułowane osobiście lub zapożyczone, ale przyjęte przez Ciebie z własnego wyboru.

Trud włożony w to zadanie - zasługujący na miano ważnego przejawu życia duchowego i odrzucany przez ludzi płytkich - może się przyczynić do lepszego zrozumienia przez Ciebie własnej historii rozwoju i własnej teraźniejszości.

Pietrasińskiemu przecież chodziło o to, aby większość jego studentów, słuchaczy i czytelników zrozumiała, że bez autobiograficznych analiz i refleksji, bez ustawicznego i samodzielnego ,wykuwania” własnego losu, pozostanie - jak odnotował 29 marca 1995 r. - „cząsteczką" zwartej masy ludzi „ubogich duchem”, pozbawionych głębi, niedojrzałych i ,anemicznych duszyczek”. Tacy ludzie nie potrafią dostrzec swych „fatalnych i nieodwracalnych niedoborów”, które wynikają najczęściej z ich nadmiernej koncentracji na materialnej stronie życia, a co za tym idzie z ,dyletanctwa we wspieraniu własnego rozwoju ku pełni człowieczeństwa”.

Tę gorzką konstatację kierował Pietrasiński nie tylko do uczniów, studentów i swych wychowanków, ale także do rodziców, nauczycieli, psychologów, pedagogów i mentorów w nadziei, że potraktują ją jak prawdziwe wyzwanie. Bo kto, jak nie oni, powinni w pełni zrozumieć sens równie gorzkiego stwierdzenia, że od niepamiętnych czasów „na fachowców kształcą nas specjaliści, a na ludzi - dyletanci"4. Wszyscy ci, którzy zamierzają to zmienić, wiedzą, że zarówno walka z już zaistniałymi „niedoborami”, jak i zapobieganie im powinny polegać na ,wykorzystaniu zasobów wiedzy i innych środków na podnoszenie jakości duchowej ludzi na równi z zabiegami o materialne warunki jakości życia. Wysoka jakość życia to przede wszystkim wysoka jakość wychowania i ludzkiej osoby, wyrastająca z wysokiej jakości życia społecznego"s. Przy tym „wysoką jakość duchową” utożsamiał Pietrasiński ze wspomnianym już dążeniem do „pełni człowieczeństwa”, rozumiejąc je jako dynamiczne ,prosperowanie duchowe” lub „duchowy rozwój”, który polega na samorealizacji w sensie trafnego uruchamia-

${ }^{3}$ Tego typu zadania, polegające na uruchomieniu i wykorzystaniu kompetencji biograficznej w celu ukształtowania postawy ukierunkowanej na „bycie kowalem swego losu”, Pietrasiński nieustannie modyfikował i wielokrotnie opisywał na kartach dziennika, co można prześledzić w opublikowanej części jego wersji komputerowej (Pietrasiński 2015, m.in. s. 15, 17, 42, 44, 167, 372, 503).

${ }^{4}$ Sformułowanie należące do kategorii wypowiedzi o najwyższej frekwencyjności, zapisane w dzienniku m.in. 4 kwietnia 1996 r.

${ }^{5}$ Wpis z 29 marca $1995 \mathrm{r}$. 
nia swego potencjału, na umiejętnym gromadzeniu i korzystaniu z wiedzy (w tym autobiograficznej) oraz życiowej mądrości, a także na „oddaniu się wyższym wartościom".

Są też takie miejsca w dzienniku, gdzie „duchowość” i ,życie duchowe” Pietrasiński utożsamia z „mądrością”. Przykładowo 5 maja 1995 r. tak sparafrazował „przykazanie” sformułowane przez Anthony’ego de Mello: „W jaki sposób duchowość (lub mądrość - Z.P. [podkr. - T.R.]) mogłaby pomóc człowiekowi światowemu, takiemu jak ja? - zapytał człowiek interesu. - Pomoże ci mieć więcej - odpowiedział Mistrz. - W jaki sposób? - Ucząc cię, byś pragnął mniej”.

Są i takie miejsca w dzienniku, gdzie Pietrasiński utożsamia ,życie duchowe" ze świadomością, jak np. w nieco przekształconym i odnotowanym 22 maja 1995 r. aforyzmie: „Człowiek szczególnie ceni życie świadome (DUCHOWE Z.P.), kiedy na inne go już nie stać”.

21 marca 2005 r. Pietrasiński dobitnie wyjaśnił:

Określenie „życie duchowe” jest tradycyjnie kojarzone głównie z życiem religijnym, dlatego celowe wydaje się operowanie szerszym i bardziej neutralnym pojęciem życia wewnętrznego. Ma ono różną intensywność, od niemal cmentarnego bezruchu i wyciszenia po natłok myśli i obrazów w chwilach natchnienia. $Z$ uwagi na formę jest ono na jednym biegunie tokiem wolnych skojarzeń, na drugim zaś - przebiega wedle określonych reguł i programów wyznaczanych przez określone zadania.

Autor komputerowego dziennika doskonale wiedział, że takie pojęcia, jak „duch”, „dusza”, „życie duchowe” czy „duchowość” jednoznacznie kojarzą się nie tyle z psychologią, co z teologią i religią oraz metafizyką i ezoteryką. Jako przykład w konsekwencji dość zabawnego „ureligijniania” tych i im podobnych pojęć, z właściwą sobie ironią podał (30 kwietnia 2004 r.) definicję szczęśliwego życia duchowego proponowaną w Talmudzie: „Oto droga Tory: będziesz jadł kromkę chleba z solą, będziesz pił miarkę wody, będziesz sypiał na ziemi i żył w troskach, ale będziesz się trudził nad Torą; jeżeli tak będziesz czynił, szczęśliwy jesteś i dobrze ci będzie. Szczęśliwy jesteś w tym życiu i dobrze ci będzie w życiu przyszłym".

\section{O RELIGII I LUDZIACH Z DOMINANTĄ ZŁUDNEJ DUCHOWOŚCI}

Pietrasiński otwarcie mówił i pisał o swym negatywnym stosunku do religii oraz do jej instytucji i wyznawców. Przykładowo 26 kwietnia 1995 r. podał taką definicję religii: to „otoczony najpowszechniejszym uznaniem zabobon, stanowiący podstawę życia duchowego ludzi zbyt niedojrzałych duchowo, by pogodzić się z przemijalnością własnego istnienia”. I kilka godzin później dopisał: „Nowa wersja przy ponownym czytaniu: Religia - czcigodny zabobon, podstawa życia duchowego ubogich duchem". 
W poszukiwaniu odpowiedzi na pytanie, dlaczego tak wielu ludzi ulega jednak ,urokowi” religijnych systemów, 2 stycznia 1996 r. Pietrasiński przypisał im (systemom) pewien pozytywny, choć i tak skrytykowany aspekt:

Pisząc o mądrości, dochodzę do nowego spojrzenia na funkcję religii w jej wersji biblijnej. To nie tylko dziedzictwo przesądów. To także poważna, rozpaczliwa i mało udana próba okiełznania zwierzęcej natury człowieka, próba tym trudniejsza, że człowiek w swej zdolności do agresji i zabijania dla władzy oraz ambicji jest istotą stokroć dzikszą i niebezpieczniejszą od wszystkich zwierząt. Krytykując tę próbę, dotąd skupiałem się na jej słabości poznawczej i dzikiej wrogości wobec życia seksualnego (rodzaj zemsty impotentów i niewolników celibatu nad resztą ludzi). Nie doceniałem zawartej w doktrynie religijnej próby okiełznania agresji, nienawiści i wzajemnego zabijania się ludzi w wyniku wrogości osobistej, plemiennej, narodowej.

Ten wyeksplikowany przez Pietrasińskiego pozytyw ginie jednak w masie treści podobnych do tych, które zawarł w kilku pytaniach retorycznych sformułowanych 24 maja 1995 r. i świadczących o preferowanym podejściu do omawianej kwestii:

Problem egzystencjalny ludzkości u progu XXI wieku: Kiedyż to ruchy robaczkowe jelit zostaną zepchnięte z centrum na margines życia wewnętrznego zwykłego człowieka? Kiedy powtarzanie pacierzy przestanie być uznawane za wykwit życia duchowego? Kiedy sacrificio dell' intelletto (ofiara z rozumu - w domyśle - na rzecz wiary) uznawana będzie jak na to zasługuje - za regres w rozwoju człowieka, regres wspierany instytucjonalnie przez Kościół...

Kościół jako instytucja „sprawująca nadzór” był przedmiotem jeszcze ostrzejszej niż religia krytyki ze strony Pietrasińskiego. Ograniczę się do jednego z łagodniejszych zapisów z 17 maja 2000 r.:

Postać zdymisjonowanego MINISTRA WSZELKIEJ DUCHOWOŚCI można uznać za metaforę papieża i Kościoła katolickiego. Krytyka tego ministra może mu zarzucać fałszywą teorię motywacji, zakładającą wystarczającą siłę grożenia karami odroczonymi. Ale teoria ta była skuteczna dla Kościoła: widmo piekła nie odstraszało od grzechów, ale skłaniało do asekurowania się ofiarami na Kościół, w wyniku czego ten stał się największym posiadaczem ziemskim na świecie. W czym Minister Wszelkiej Duchowości (Kościół) okazał się skutecznym użytkownikiem psychologii? W genialnej eksploatacji skłonności ludzi do myślenia życzeniowego.

Podobnie otwarcie i wielokrotnie, bez ogródek i zawoalowania, Pietrasiński wyrażał swój negatywny stosunek do ludzi „zaślepionych wiarą”, „duchowo niedojrzałych”, posłusznie i potulnie ,zapatrzonych w to, co Kościół i religia" do wierzenia podają. Zresztą co tu kryć - właśnie takie osoby zaliczał do grona ludzi „niepełnych”, o „zaszpuntowanych umysłach”, „sztywnych poznawczo”, więc raz na zawsze „przekonanych o swej nieomylności”, a jednocześnie epatujących rzekomo wyłącznie im przysługującą duchowością. W dzienniku znajduje się aż nadto wypowiedzi świadczących o jednoznacznie odrzucającej posta- 
wie Pietrasińskiego wobec systemów religijnych, wobec Kościoła i innych podobnie „sztywnych” instytucji oraz ich reprezentantów, a także wobec dokumentów i dzieł (zwłaszcza religijnych) narzucających „obowiązkowe” i niepodlegające dyskusji ,pewniki”. Oto kilka dobitnych przykładów.

10 października 1994 r.:

Metafora ilustrująca głupotę i niedojrzałość ludzi nobilitujących ślepą wiarę w wyniku obserwacji nad ograniczonością ludzkiego poznania. Pewien wędrowiec potknął się, idąc przez las i upadł. A ponadto zmylił kierunek. (...) Zły na siebie powiedział: „Moje spostrzeganie i myślenie jest ułomne. Wobec tego będę dalej szedł z zamkniętymi oczami”. I poszedł, obrażony na swój niedoskonały umysł. Jak go nazwiecie? Głupcem? Istotą zadziwiająco infantylną? Ale zastanówcie się, zanim użyjecie takich określeń. Wszak ludzi podobnie postępujących w sprawach znacznie ważniejszych otaczacie w pewnych warunkach czcią. Czym bowiem różni się nasz wędrowiec od człowieka, który z wiedzy o ograniczeniach naukowego poznania wyciąga wniosek, że należy zdać się na wiarę w duchy, zaświatowe moce, cuda i zaklęcia magiczne? Oczywiście kolejność zdarzeń jest w zachowaniu tego człowieka inna od opisanej. On najpierw, jako naiwne dziecko, został wprowadzony w krąg kultu ślepej wiary. Gdy później szuka dla niej uzasadnień, nie są mu potrzebne żadne sensowne dowody. Jego myślenie jest myśleniem życzeniowym. Chce podtrzymać swą wiarę i zadowoli się byle jakim uzasadnieniem, bo żadne sensowne uzasadnienie nie jest mu potrzebne. (...) Zdolność do bezkrytycznej wiary bywa chwalona, a wątpienie potępiane i nawet karane. Karane dawniej stosem, dziś - posądzeniem o ograniczoność... Ale nie chowajmy głowy w piasek: łatwowierność i irracjonalna wiara podnoszona do rangi rozwoju duchowego i cnoty służyła już wielokrotnie jako narzędzie lub przyzwolenie dla prześladowań, zbrodni i ludobójstwa. Inkwizycja zabiła w imię miłości więcej niż milion ludzi. Fanatyczni rasiści i przywódcy polityczni popełniali swe zbrodnie dzięki tym, którzy łatwo i ochoczo wierzą w to, co się im stanowczo narzuca i w co chcą wierzyć. (Chwalić wypada wierzących katolików za to, że ich wiara jest taka niekonsekwentna i że wierząc w życie wieczne, nie poświęcają dlań, jak niektórzy gorliwcy, życia, jakie mają.)

\section{0 września 1994 r.:}

Człowiek pierwotny na etapie animizmu wierzył w posiadanie duszy przez wszystkie przedmioty i zwierzęta. Dziś można w to wierzyć, lecz są powody, by wiarę taką odrzucić bez uznania, że ten, kto ją podziela, stoi w jednym rzędzie z umysłem wykształconym, który liczy się z ograniczeniami ludzkiego poznania. Kultura metodologiczna współczesnej nauki przemawia za relatywizmem wiedzy, ale z trudności poznania nie wynika aprobata dla dowolnych spekulacji. Paradoks: ludzie, którzy wierzą w pewne rzeczy dlatego, że tak im się po prostu podoba, próbują wywyższyć swą postawę, powołując się na to, że nauka ma trudności metodologiczne. Właściwą istocie rozumnej reakcją na te trudności jest mówić: „Nie wiem”, a nie: „W takim razie ten, kto wierzy w co chce, jest jako istota obdarzona rozumem równy lub nawet lepszy od tego, kto żywi wątpliwości i testuje propozycje uwierzenia w coś pytaniem, co przemawia za odrzuceniem tej wiary”.

\section{3 lipca 2003 r.:}

Przed wyjazdem na wieś zapisuję wyniki nocnej inkubacji (...). Wielka idea 1: Ludzie (fideiści) stworzyli wielką mistyfikację. Pojęcie „życie duchowe”, „uduchowienie”, cieszy się estymą. Jeśli ktoś wierzy w anioły i diabły - jest uduchowiony, ale jeśli jest sceptyczny wobec tej wiary - jest uduchowiony bardziej, ALE UWAŻA SIĘ, że jest odwrotnie. 


\section{5 lipca 2004 r.:}

Lektura Heideggera prowadzi do rozszerzenia psychologicznego pojęcia tożsamości. Zwykle określenie tożsamości - czyli stałego ,ja” jednostki - sprowadza się do tożsamości w skali ostatniego czasu lub własnego życia; tożsamości uściślanej przez charakterystykę kolejnych pełnionych ról, stylu życia itp. Do takiej charakterystyki należy dodać (...) tożsamość dziejową, albowiem jestestwo jest według $\mathrm{H}$ [eideggera] istotą dziejową. Najczęściej namiastką takiej tożsamości jest poczucie przynależności do określonego narodu. (...) W tej skali tożsamość przeciętnego Polaka to tożsamość uczestnika cywilizacji technicznej, a zarazem istoty gwałconej w dzieciństwie duchowo przez zaszczepianie określonej religii (jednej z wielu, narzucanej w wyniku takiego a nie innego miejsca urodzenia) i uodpornianej przez zabiegi wychowawcze na samodzielną jej ocenę w przyszłości.

\section{3 maja 2007 r.:}

Po krytyce narzekań na ludzi współczesnych (w tym: „Człowiek współczesny to istota rozumna, poświęcająca każdą wolną chwilę na oglądanie idiotycznych filmów telewizyjnych”). Uogólnię tę krytykę tak: Ludzie nie wykorzystują potencjału pozwalającego im być wspanialszymi ludźmi. Bieg historii jak dotąd sprzyjał formowaniu umysłów płytkich, bezkrytycznych, podatnych na myślenie życzeniowe i fanatyzm. Takie umysły łatwiej podporządkowują się władzy duchowej i świeckiej.

I czyż nie o to chodzi w najogólniejszym rozrachunku? Takie pytanie leży u podstaw całożyciowych dążeń Pietrasińskiego do osiągnięcia najistotniejszego celu, jakim dlań było formowanie osób, które - zdobywszy mistrzostwo w sztuce życia - mogły i umiały przeciwstawić się zakusom i presji ze strony władzy czy to świeckiej, czy kościelnej. Dawał temu wyraz nie tylko w dzienniku, lecz w codziennej pracy dydaktycznej oraz w książkach i artykułach poświęconych sztuce życia. Nawoływał wszystkich, którzy mają wpływ na kształtowanie młodych ludzi, aby stawali się fachowcami w tej dziedzinie i odpowiedzialnie formowali swych wychowanków na osoby stale doskonalące się w sztuce życia, rozumiejące jego sens i zmierzające ku ,pełnemu człowieczeństwu” przez indywidualne, krytyczne i surowe testowanie twierdzeń podawanych im do wierzenia.

To dzięki zakładanej aktywności i odpowiedzialnej pracy mentorów Pietrasiński liczył na renesansową „ekspansję pięknych umysłów”, czyli osób samorealizujących się, a więc zintegrowanych wewnętrznie, otwartych na nowe doświadczenia i innych ludzi, zdolnych do zaspokajania swych potrzeb w stałym kontakcie ze światem, ale i do odrzucania ograniczeń zewnętrznych w imię uznawanego systemu wartości. Takie osoby cenią naukę i sztukę, stale uzupełniają zasoby własnej wiedzy i mądrości życiowej oraz dbają o zaspokajanie potrzeb najwyższego rzędu. 
W tym miejscu warto przytoczyć definicję zapisaną 5 kwietnia 2003 r.:

Pełny to niekoniecznie osobnik renesansowo wszechstronny. Pełnia dotyczy rozwoju potencjalnego, unikalnego przymiotu człowieka, który przez kulturę, przez życie społeczne jest teoretycznie wspomagany, a w praktyce - zarazem tłumiony w imię władzy nad ludźmi... Jest to świadome, pracowite i wymagające wielkiej odwagi przezwyciężenie zniewolenia duchowego. Zniewolenia tym trudniejszego do przezwyciężenia, gdy nie stoją za nim żadni krwawi dyktatorzy, lecz osoby otoczone czcią i postrzegane jako pełne najlepszych i bezinteresownych intencji. Jest to refleksyjność wraz z jej najtrudniejszą formą - refleksyjnością wobec wpojonego w dzieciństwie dziedzictwa ideologicznego.

\section{ROZWÓJ DUCHOWY}

Jak Pietrasiński wyobrażał sobie proces nazwany przezeń metaforycznie rozwojem duchowym, polegający na umiejętnym ,wykuwaniu” własnego losu, czyli na stosowaniu takich reguł sztuki życia, które umożliwią osiągnięcie pełni człowieczeństwa i uformowanie ,pięknego umysłu”? Niewątpliwie za podstawę rozwoju duchowego uznał on mądrość. Przez większość kart dziennika przewija się bowiem ta podstawowa refleksja, którą po raz pierwszy odnotował 20 sierpnia 1992 r.:

Mądrość jest przymiotem, którego rozwój niezawodnie doprowadzi do postawienia sobie przez jednostkę problemu sztuki życia i nada tej sztuce nową rangę. Ponieważ menedżerowie i kandydaci na nich wolą słyszeć o instrumentach niż o celach - zaczęcie zajęć z nimi od mądrości jako instrumentu prędzej doprowadzi do poważnego potraktowania z czasem - po serii zajęć - problematyki sztuki życia i rozwoju duchowego niż przyjęcie drogi odwrotnej. Tak więc temat gorący - mądrość - jest w mej dydaktyce nową dźwignią rozwoju i zarazem archimedesowym punktem oparcia dla tej dźwigni (Pietrasiński 2015, s. 25).

Kiedy Pietrasiński poszukiwał trafnej definicji pojęcia „rozwój duchowy”, to chętnie - jak zwykle - sięgał do lektur i odnalezionych tam podpowiedzi. Na przykład 14 kwietnia 1996 r. wyczytał „o rozróżnianiu przez Przybyszewską w człowieku siebie danego i siebie wybranego (...). Rozwój duchowy polega na wyjściu z siebie danego, walkę tego, co wybrane z tym, co dane. Podobnie myśli Gombrowicz, mówiąc o niegodzeniu się na siebie urobionego przez historię". Do tej kwestii powrócił, potwierdzając wcześniejsze rozumienie „,rozwoju duchowego", 15 września 1996 r.:

U Przybyszewskiej zarysowuje się ,jak gdyby cała teoria człowieka jako istoty dwoistej” [podkr. - Z.P.]. Człowiek jest tym, co dane (to właśnie to, co psychiczne) i jest zadaniem sam dla siebie (na tym właśnie polega dojście do stanu mentalnego). Wobec tego historia człowieka przedstawia nam się jako jego rozwój wewnętrzny, jako praca duchowa i psychomachia jednocześnie, walka z sobą samym, wyjście z owego stanu danego. 
W pierwszym spośród nakreślonych w dzienniku modeli rozwoju duchowego, wzorowanym na koncepcji Abrahama Maslowa, Pietrasiński zakładał, że sens i cel rozwoju polega na przechodzeniu od zaspokajania potrzeb podstawowych, podyktowanych ,zewnętrznymi” wymogami życiowymi i społecznymi, do skupienia się na własnych i autonomicznie określonych potrzebach wyższego rzędu. Osiągnięcie tego celu pozwala na przypisanie „dojrzałości osobowościowej” tak rozwijającemu się człowiekowi. Tę prawidłowość rozwojową opisał 27 stycznia $1997 \mathrm{r}$ :

Na niższym etapie rozwoju jakość życia mierzona jest głównie stopniem zaspokojenia potrzeb elementarnych. A najpopularniejsze środki do tego celu są dwa, i to przeciwstawne:

1. Dążenie do większego komfortu materialnego i wyższej pozycji społecznej. Najogólniej: rywalizacja o dobra zewnętrzne, o bardziej komfortowe zaspokajanie potrzeb. Mamy tu taką drogę:

\section{UBÓSTWO $\rightarrow$ ROZWÓJ MATERIALNY $\rightarrow$ KONIEC ROZWOJU}

2. Wyłączenie się z rywalizacji, akceptacja aktualnego stanu i redukcja standardów zaspokajania potrzeb w stosunku do istniejących w danym społeczeństwie wzorów. Odbywa się ona na drodze rezygnacji o dwóch motywach. Jednym jest niezdolność do rywalizacji i znalezienie większego komfortu w poprzestaniu na status quo niż w walce o lepszą pozycję materialną i społeczną. Drugi motyw ma naturę ideologiczną i jest propagowany przez kapłanów i filozofów. Uzasadnia on rezygnację, wskazując na wyższość poprzestawania na małym, bo to podoba się bóstwu lub wyróżnia dodatnio jednostkę i uwalnia od ścigania iluzji.

$\mathrm{Na}$ wyższym etapie rozwoju komfort materialny daje impuls do rozwoju duchowego. Mamy więc takie drogi:

Droga pierwsza:

UBÓSTWO $\rightarrow$ ROZWÓJ DUCHOWY JAKO JEDYNIE DOSTĘPNY $\rightarrow$ ZABLOKOWANIE ROZWOJU MATERIALNEGO.

Przykładem wydatnego sukcesu na tej drodze są tu mnisi buddyjscy, promieniujący radością życia. Ich przeciwieństwem są mnisi chrześcijańscy, kultywujący ponure życie cierpiętnicze, pojmujący rozwój duchowy jako tłumienie zmysłowości.

Droga druga:

$$
\text { UBÓSTWO } \rightarrow \text { ROZWÓJ MATERIALNY } \rightarrow \text { ROZWÓJ DUCHOWY, }
$$

wspomagany dzięki osiągnięciom nauki uwarunkowanym przez rozwój materialny. Buddysta pozostaje przy kanonie starej wiedzy, człowiek Zachodu poznaje buddyzm, ale jest bogatszy o naukową psychologię etc.

Po wielu zmianach i pogłębionych refleksjach 15 lutego 2005 r. Pietrasiński doszedł do wniosku, że zamiast mówić o rozwoju duchowym, warto się posługiwać terminem „rozwój wewnętrzny”: 
(...) przechodzę do pojęcia życia duchowego. Ponieważ jest ono zawłaszczone przez religię z jej gloryfikacją duchowości jako bezmyślnej wiary, klepania pacierzy, magicznych praktyk w rodzaju modlenia się o różne rzeczy, używanie go lokuje nas od razu w fatalnym kontekście. Moja propozycja: Uczmy się mówić o życiu i rozwoju wewnętrznym, a nie duchowym.

Nieco wcześniej uznał, że wszelkie przejawy życia wewnętrznego, czy chodziłoby tu o „naukowe odkrycia” lub ,akty sokratejskiego sceptycyzmu” czy też o „modły” lub ,akty ślepej wiary”, różnią się jedynie i przede wszystkim tym, że pochodzą ,z różnych poziomów zaawansowania tego życia”. Aby zatem zbudować model ich rozwoju, najpierw należy je umiejscowić w kontekście rzeczywistym, a dopiero potem przejść do ewaluacji i ustanowienia rangi owych poziomów. Tak też uczynił, gdyż 24 lipca 2003 r. - wzorem Karla Poppera - wyróżnił trzy „światy” lub „sfery ludzkiego życia”, a charakteryzując je, zasygnalizował w sferze trzeciej „obecność” możliwych poziomów rozwoju wewnętrznego. Tym samym zaproponował nowy model rozwoju wewnętrznego, nie tyle opierający się na dynamice jednostkowych potrzeb i sposobów ich zaspokajania, ile na indywidualnych odkryciach niedostatków i błędów w wiedzy społecznej oraz na przyjmowaniu wobec niej prawdziwie kartezjańskiej postawy, prowadzącej do weryfikacji treści podawanych do wierzenia, a następnie do budowania - dzięki mądrości - własnej wiedzy złożonej z dojrzałych, tj. osobiście sprawdzonych przekonań.

Według Pietrasińskiego (24 lipca 2003 r.) zatem każdy człowiek funkcjonuje w trzech światach, które można scharakteryzować następująco:

CECHY ŚWIATA (SFERY) I: Tworzy środowisko i nasz organizm, daje poznanie zmysłowe, rozwijające się w abstrakcyjne poznanie naukowe. Jest to najbardziej neutralny obiekt poznania. Na ten świat skierowane są powtarzalne czynności produkcyjne dające impuls i okazję do doskonalenia technologii i tworzenia z czasem nauki. Świat ten dostarcza najlepszej weryfikacji efektów działania i wyników poznania, lepszej niż świat społeczny, znacznie trudniejszy dla eksperymentowania i poznania.

CECHA ŚWIATA (SFERY) II: Interesy społeczne narzucają przesądy, cenzurują wypowiedzi.

CECHA ŚWIATA (SFERY) III: Jest najbardziej prywatny i dostępny w swej introspekcyjnej treści bezpośrednio tylko danej osobie. Dwa światy poprzednie tworzą scenę zewnętrzną, widoczną dla wszystkich, ten - jest ,sceną wewnętrzną”. Zafałszowanie wiedzy o tym świecie wynika nie tylko z trudności jego poznania, lecz z tego, że samopoznanie jest dla człowieka wiedzą gorącą, stanowiącą dlań - na niższym szczeblu rozwoju - podstawę znaku samooceny. Potrzeba posiadania pozytywnej samooceny sprawia, że ludzie szukają nie tyle wiedzy o sobie, co pozytywnej wiedzy o sobie i automatycznie zafałszowują wiele zależności (por. błędy atrybucji, racjonalizacja, projekcja i inne mechanizmy obronne). Przejście na wyższy poziom rozwoju wewnętrznego wymaga wyzwolenia się spod tych ograniczeń, zafałszowań, mistyfikacji, całego zakłamania wewnętrznego na służbie pozytywnej samooceny osoby psychicznie słabej.

W tym właśnie III świecie człowiek musi wykonać najbardziej osobistą, własną i często bolesną pracę poznawczą, która znajduje nieporównanie mniejsze wsparcie z zewnątrz niż poznawanie świata I i II. Jej wynikiem jest m.in. pokonanie mylnego poczucia sprawstwa wszędzie tam, gdzie przyswojone bezrefleksyjnie, często narzucone w dzieciństwie opinie jawią się jednostce jako prze- 
jawy jej wolnego, osobistego wyboru. Fanatyk religijny, polityczny i każdy inny działa w przekonaniu o jedynie słusznej i głęboko osobistej racji, nie będąc w stanie spojrzeć na uwarunkowania tej racji przez narzuconą mu wcześniej tresurę światopoglądową etc. Bez zdolności do zdystansowania się od podobnego dziedzictwa ludzie od tysiącleci zabijają się wzajemnie i nienawidzą, pozostając w stanie złowieszczego zezwierzęcenia, a mówiąc językiem ewolucji wewnętrznej - „niedoczłowieczenia", połączonego często z subiektywnym - też narzuconym z zewnątrz - poczuciem uduchowienia. Uduchowienie godne Homo sapiens nie bazuje na pokornej akceptacji zastanych stereotypów. Drogą do niego nie jest zabijanie zdolności do samodzielnej refleksji, lecz właśnie rozwijanie jej jako instrumentu duchowej autonomii. Nie autonomii pozornej, fascynującej młodych ludzi, krytykujących z poczuciem wyższości dorosłych z równoczesnym naśladowaniem ich najgorszych przywar (palenia, picia etc.) jako rzekomych przejawów autonomii i dojrzałości. Wzorem rewizji wszechstronnej jest kartezjańskie zawieszenie wszystkich dotychczasowych opinii do czasu wytrzymania przez każdą z nich testu intelektualnej oceny.

Świat III rozwija się jako świadomość i tworzy podstawę samoregulacji zachowania na podstawie nowej wiedzy. Dostępu do jego poznawania broni więcej barier niż w światach I i II. Nawet zdrowy rozsądek natrafia tu na skryty i skuteczny opór mechanizmów obronnych, a myślenie życzeniowe łatwo bierze górę nad racjonalnym.

Do tych wstępnych pomysłów i wyjaśnień teoretycznych Pietrasiński dodawał co pewien czas uzupełnienia, wzbogacając naszkicowany model rozwoju wewnętrznego o nowe treści. I tak 10 stycznia 2004 r. zajął się opisem jego najniższego poziomu:

Ad teoria. Nowe. Co decyduje o wydatnym rozwoju kompetencji autokreacyjnej w strefach II i III? Zapytajmy, jakie zadania autokreacyjne w tych strefach są istotne?

Pierwsze i najistotniejsze: stawania się (w coraz większym stopniu) OSOBĄ. Co jest przed CZŁOWIEKIEM-OSOBĄ? CZŁOWIEK SYNKRETYCZNY, czyli niedostatecznie zróżnicowany wewnętrznie, gdy idzie o stosunek do siebie i dziedzictwa... Przykładem najjaskrawszym jest tu fanatyk: on nie jest zdolny spojrzeć z dystansu, krytycznie, na swoje skrajne, przejęte z zewnątrz przekonania, na siebie... Zaś przykładem najpowszechniejszym jest zwykły człowiek, który ma niezachwiane poglądy na liczne sprawy, jest przekonany, że zawsze ma rację i nie jest zdolny do wysłuchania jakiejkolwiek krytyki pod własnym adresem, jest przez historię swej edukacji zniewolony, ma umysł jakby zaszpuntowany. Najniższy poziom rozwoju duchowego: według Kierkegaarda - człowiek bezpośredni (budzi mylne skojarzenia) (Z.P.: niezdystansowany, SYNKRETYCZNY [w terminologii Obuchowskiego], czyli bez dystansu wobec siebie i dziedzictwa, nieumiejący spojrzeć na siebie z boku jak na przedmiot analizy, czyli człowiek PRZEDPODMIOTOWY, a przez to niezdolny do prawdziwego samostanowienia, do bycia sobą w rozumieniu Rogersa) - niezdolny do refleksji, panowania nad sobą, zależny od innych ludzi...

15 lutego 2005 r. do tej charakterystyki dodał jeszcze kilka określników, aby nie było wątpliwości, kogo i z jakiego powodu należy zaliczyć do opisanego typu ludzi umieszczonych na niskim (,pierwotnym”) poziomie rozwoju wewnętrznego. Według Pietrasińskiego takie osoby cechuje ,bezkrytyczna wiara” oraz ,ignorowanie zasady dostatecznej racji”. Podstawową formą ich aktywności są natomiast „modły jako działania magiczne”. 
30 kwietnia 2004 r. Pietrasiński również zajmował się uzupełnianiem szkicowanego modelu rozwoju wewnętrznego. Tym razem zająl się opisem ludzi, którzy wspięli się na wyższe poziomy rozwoju.

IDEAŁ PEŁNI. Przed nim - LUDZIE SĄ POŁOWICZNI. (...) Połowicznym jest człowiek rozwinięty w zawodzie, a niekompetentny w sferach II i III. Nasza kultura, a jeszcze bardziej islamu - produkuje ludzi połowicznych. (...) Ideał podwójnego eksperta albo mędrca brzmi źle. Uznaję za najlepsze sformułowanie - niejasne bez dodatkowego opisu - ideał pełni. Oznacza on stałe nastawienie na rozwój. Pełnia zawsze może być większa. Ale w jakich kierunkach ma się do niej przybliżać jej zwolennik? To jest do określenia przez każdą zainteresowaną osobę. (...) W moim ujęciu oznacza to ideał podwójnego eksperta. W ideale tym mieści się dystansowanie, osiągane metodą praktykowania roli własnego oponenta.

Rolę czy metodę ,własnego oponenta” rozumiał Pietrasiński jako jedną z najważniejszych „kompetencji osobotwórczych”, polegającą na umiejętności dystansowania się wobec siebie i własnych pomysłów i co za tym idzie na poszukiwaniu kontrargumentów oraz podejmowaniu dyskusji z pozycji przeciwstawnej do zajmowanej na wyjściư .

Podobnie jak w wypadku ludzi ulokowanych na pierwotnym poziomie rozwoju wewnętrznego, tak i wobec osób znajdujących się na poziomie wysokim (,zaawansowanym”) 15 lutego 2005 r. Pietrasiński dodał kilka charakterystyk. Miały one pozwolić na sprawne i szybkie ocenianie poziomu rozwoju wewnętrznego, na którym znajduje się dowolna osoba. Jeżeli zatem ta osoba przejawia „wątpienie w otrzymany przekaz społeczny” i jeśli za „racjonalne działanie” uważa „badanie warunków osiągania celów”, a przy tym potrafi „stosować zasadę dostatecznej racji”, to z pewnością osiągnęła wysoko wartościowany poziom rozwoju wewnętrznego. Pietrasiński nie byłby sobą, gdyby nie dodał, że przy takim ujmowaniu najwyżej przezeń ocenianego poziomu rozwoju ,wiele aktów, nobilitowanych zwyczajowo przez samo nazwanie ich duchowymi, spada do poziomu mentalnego prymitywizmu". Ponieważ wszystko to, co niemal odwiecznie zwykło się kategoryzować jako „duchowe”, zostało nam narzucone, więc ma niewiele wspólnego z uczeniem się na podstawie własnych doświadczeń, a tym samym ma niewiele wspólnego z mądrością i rozwojem wewnętrznym.

Zamiast zakończenia jeszcze jedna myśl Zbigniewa Pietrasińskiego ( 5 czerwca 1998 r.), bodaj najtrafniej podsumowująca rozważania zawarte w tym tekście: „Porównajmy mądrość do pięknej góry. Nie musimy koniecznie wejść na jej niebotyczny szczyt, by czuć się zdobywcą. Kolejne kroki po jej zboczu poszerzają nasz widok na dolinę życia".

${ }^{6} \mathrm{O}$ korzyściach $\mathrm{z}$ wchodzenia $\mathrm{w}$ rolę oponenta i o zasadach stosowania tej techniki można znaleźć wzmianki m.in. na s. 300, 301, 383, 404, 405, 417, 421 Dziennika ... (Pietrasiński 2015). 


\section{BIBLIOGRAFIA}

Bühler C. (1933/1999), Bieg ludzkiego życia jako problem psychologiczny, Warszawa: Wydawnictwo Naukowe PWN.

Pietrasiński Z. (1977), Kierowanie własnym rozwojem, Warszawa: Wydawnictwo Naukowe „Iskry”.

Pietrasiński Z. (1979), Czego dowiedziałeś się zbyt późno?, Warszawa: Wydawnictwo Naukowe „Iskry”.

Pietrasiński Z. (1987), Człowiek formowany jako podmiot rozwoju, „Psychologia Wychowawcza", nr 30.

Pietrasiński Z. (1988), Rozwój i perspektywy jego podmiotu, [w:] M. Tyszkowa (red.), Rozwój psychiczny człowieka w ciagu życia, Warszawa: Państwowe Wydawnictwo Naukowe.

Pietrasiński Z. (1990), Rozwój człowieka dorosłego, Warszawa: Wiedza Powszechna.

Pietrasiński Z. (1992), Wiedza i ,rola” autokreacyjna jednostki jako przedmiot rozwoju, „Przegląd Psychologiczny", nr 1.

Pietrasiński Z. (1993), Syntezy wiedzy autobiograficznej podporządkowane „,roli” autokreacyjnej jednostki, [w:] T. Rzepa, J. Leoński (red.), O biografii i metodzie biograficznej, Poznań: Nakom.

Pietrasiński Z. (2001), Mądrość, czyli świetne wyposażenie umysłu, Warszawa: Wydawnictwo Naukowe Scholar.

Pietrasiński Z. (2003), Jakość życia a jakość osoby: perfekcyjne ksztatcenie i zaniedbane wychowanie, „Psychologia Jakości Życia”, nr 2.

Pietrasiński Z. (2009), Ekspansja pięknych umystów. Nowy renesans i ożywcza autokreacja, Warszawa: Wydawnictwo CIS.

Pietrasiński Z. (2015), Dziennik komputerowy z [...], Lublin: Wydawnictwo UMCS.

Pietrasiński Z. (red.) (1997), Studenci o własnym rozwoju, Warszawa: Wydawnictwo Instytutu Psychologii PAN, SWPS.

Pietrasiński Z. (red.) (2000), Uczeni o sobie i studentach, Warszawa: Wydawnictwo Instytutu Psychologii PAN.

\section{SUMMARY}

In the article there are presented Zbigniew Pietrasiński's views on: 1) understanding concepts of "spirit", "soul" and "spirituality", 2) catholic religion, its believers and The Roman Catholic Church, 3) the essence and sequence of events in the model understanding of spiritual development, which are included in his computer diary.

Keywords: Zbigniew Pietrasiński’s views; soul; spirituality; spiritual development 